\section{Control of Insect Pests and Diseases in an Ohio Fruit Farm with a Laser-guided Intelligent Sprayer}

\author{
Liming Chen ${ }^{1}$, Matthew Wallhead ${ }^{2}$, Michael Reding ${ }^{1}$, \\ Leona Horst ${ }^{1}$, and Heping $\mathrm{Zhu}^{1}$
}

AdDitional INDEX wORDs. apple, blueberry, environmental protection, peach, pest control, pesticide, precision agriculture, precision sprayer

SUMMARY. Laser-guided variable-rate intelligent spray technology is designed to significantly reduce pesticide use with a positive impact on the environment. However, there have been no reports on applying this technology to commercial fruit farms. Comparative experiments of intelligent variable-rate and conventional constant-rate spray applications for pesticide use and pest control were conducted at a fruit farm in Ohio during two consecutive growing seasons. Apple (Malus pumila), peach (Prunus persica), blueberry (Vaccinium section Cyanococcus), and black raspberry (Rubus occidentalis) were used for the tests. Pest severity of codling moth (Cydia pomonella), oriental fruit moth (Grapholitha molesta), scab (Venturia inaequalis), and powdery mildew (Podosphaera leucotricha) in apple; oriental fruit moth, brown rot (Monilinia fructicola), and powdery mildew (Podosphaera pannosa) in peach; spotted wing drosophila (Drosophila suzukii), mummy berry (Monilinia vaccinii-corymbosi), and phomopsis (Phomopsis vaccinii) in blueberry; and anthracnose (Elsinoe veneta) in black raspberry were assessed. There was equal severity of pests between intelligent and conventional spray applications, whereas the intelligent spray reduced pesticide use by $58.7 \%, 30.6 \%, 47.9 \%$, and $52.5 \%$ on average for apple, peach, blueberry, and black raspberry, respectively. These results illustrate that intelligent spray technology is more environmentally friendly than conventional standard spray technology and equally or more effective for control of insect and disease pests in fruit production.

I $\mathrm{n}$ commercial fruit production in the midwestern United States, producers usually employ integrated pest management (IPM) to control a variety of insect and disease pests (Beckerman, 2018). IPM tactics include removing leaf litter and pruning out infected sections of plants, use

Received for publication 30 Aug. 2019. Accepted for publication 26 Dec. 2019.

Published online 3 February 2020.

${ }^{1}$ Application Technology Research Unit, Agricultural Research Service, U.S. Department of Agriculture, 1680 Madison Avenue, Wooster, OH 44691

${ }^{2}$ University of Maine Cooperative Extension, 495 College Avenue, Orono, ME 04473

This research was supported by the U.S. Department of Agriculture (USDA), National Institute of Food and Agriculture, Specialty Crop Research Initiative Project 2015-51181-24253. We acknowledge Fred Finney, Steve Finny, and Moreland Fruit Farm for their generosity to provide facilities, labor, and resources for the experiments. Mention of proprietary product or company is for the reader's convenience and does not imply any endorsement or preferential treatment by USDA, Agricultural Research Service.

H.Z. is the corresponding author. E-mail: heping. zhu@usda.gov.

This is an open access article distributed under the $\mathrm{CC}$ BY-NC-ND license (https://creativecommons.org/ licenses/by-nc-nd/4.0/).

https://doi.org/10.21273/HORTTECH04497-19 of mating disruption of insects, application of pesticides and biological agents, and monitoring pests to optimize timing of management actions (Beckerman, 2018; UMass Extension, 2018). Among these pest control techniques, pesticide applications are essential to ensure yield and quality for the conventional nonorganic fruit industry (UMass Extension, 2018). According to the Midwest Fruit Pest Management Guide (Beckerman, 2018), apple and peach need to be sprayed $\approx 16$ and 11 times in 1 year, respectively, and blueberry and black raspberry need to be sprayed approximately seven and five times, respectively.
For applying pesticides to control insect pests and diseases in fruit farms, the most commonly used spray equipment is radial air-assisted sprayers (Zhu et al., 2017). These conventional sprayers deliver pesticides at a constant rate and usually apply pesticides to the entire field regardless of plant absence or plant structure variation, resulting in underspraying or overspraying (Zhu et al., 2008). A large proportion of the spray drift is delivered to nonplant areas, such as ground and air (Zhu et al., 2006a), leading to pesticide loss and risk of environmental contamination, which increases the costs of production and exposure to pesticides for applicators, workers, and other people near the farms. A wide range of spray methods has been evaluated to improve the delivery of pesticides (Stover et al., 2003; Zhu et al., 2006a, 2006b, $2011 \mathrm{a}, 2011 \mathrm{~b}$ ).

To increase the efficiency of pesticide use on fruit farms, a laser-guided variable-rate intelligent sprayer was developed (Chen et al., 2012; Shen et al., 2017). The sprayer discharges appropriate variable amounts of pesticides in real time. Application rate is controlled by adjusting the spray output of each nozzle based on the presence, structure, and foliage density of plants, and sprayer travel speed. Chen et al. (2013a) reported the intelligent variable-rate sprayer reduced spray volume by $57 \%$ at the full-foliage stage and $73 \%$ at the leafing stage of apple while remaining comparable spray deposition on target areas compared with a conventional constant-rate sprayer. In an experiment with multiple-row nursery trees, 'Sterling' silver linden (Tilia tomentosa) and northern red oak (Quercus rubra), Zhu et al. (2017) found no difference in spray deposition and coverage on the trees between intelligent variable-rate and conventional constant-rate spray applications, despite the intelligent variable-rate application discharging significantly less spray vol-

\begin{tabular}{llll}
\hline $\begin{array}{l}\text { Units } \\
\text { To convert U.S. to SI, } \\
\text { multiply by }\end{array}$ & U.S. unit & SI unit & $\begin{array}{l}\text { To convert SI to U.S., } \\
\text { multiply by }\end{array}$ \\
\hline 0.4047 & $\mathrm{acre}(\mathrm{s})$ & $\mathrm{ha}$ & 2.4711 \\
0.3048 & $\mathrm{ft}$ & $\mathrm{m}$ & 3.2808 \\
3.7854 & $\mathrm{gal}$ & $\mathrm{L}$ & 0.2642 \\
9.3540 & gal/acre & $\mathrm{L} \cdot \mathrm{ha}^{-1}$ & 0.1069 \\
2.54 & inch(es) & $\mathrm{cm}$ & 0.3937 \\
1.6093 & $\mathrm{mph}$ & $\mathrm{km} \cdot \mathrm{h}^{-1}$ & 0.6214 \\
6.8948 & $\mathrm{psi}$ & $\mathrm{kPa}$ & 0.1450 \\
$\left({ }^{\circ} \mathrm{F}-32\right) \div 1.8$ & ${ }^{\circ} \mathrm{F}$ & ${ }^{\circ} \mathrm{C}$ & $\left({ }^{\circ} \mathrm{C} \times 1.8\right)+32$ \\
& & & \\
\hline
\end{tabular}


ume ultimately resulting in substantial pesticide use reductions. However, there have been concerns on applying this technology to commercial fruit farms regarding whether insect and disease pests can be effectively controlled with such great reductions in pesticide use.

Codling moth is the most serious pest of apple in the United States (Beckerman, 2018). In nonorganic apple orchards, insecticide treatments are the most common method of controlling codling moth (Amarasekare and Shearer, 2017). For most insecticides, the initial applications should be timed to coincide with hatch of codling moth eggs (Brunner, 1993).

Oriental fruit moth is one of the most damaging pests of peach. It also attacks apple in eastern U.S. applegrowing districts (Brunner and Rice, 1993). Mating disruption and insecticide sprays are the two major strategies for controlling it in peach. Insecticide sprays should be applied before young larvae bore into shoots or fruit (Brunner and Rice, 1993).

Spotted wing drosophila has been a serious pest of black raspberry, blueberry, strawberry (Fragaria ×ananassa), sweet cherry (Prunus avium), and grape (Vitis sp.) in the
United States over the past 10 years. Blueberry fruit is susceptible to spotted wing drosophila from the time it begins to color and becomes increasingly susceptible as the fruit ripen (Fulcher et al., 2015). Without insecticide treatments, yield of blueberry may be reduced by $30 \%$ to $100 \%$ (Fulcher et al., 2015). Spraying insecticides is the main method of controlling spotted wing drosophila in fruit crops worldwide (Haye et al., 2016). In Switzerland, $\approx 80 \%$ of sweet cherry growers in 2015 and 2016 used insecticides to control spotted wing drosophila (Mazzi et al., 2017).

Apple scab caused by the fungus Venturia inaequalis is a serious disease and occurs worldwide, leading to the greatest loss in apple yield among apple diseases (Ellis, 2008). Powdery mildew of apple caused by the fungus Podosphaera lencotricha also occurs worldwide in all apple-producing regions. The disease decreases flower bud production and fruit quality (Ellis, 2016a). Good fungicide spray programs (e.g., applying prebloom fungicide spray and shortening the spray interval) are major approaches of controlling these diseases.

Brown rot caused by fungus Monilinia fructicola is the most

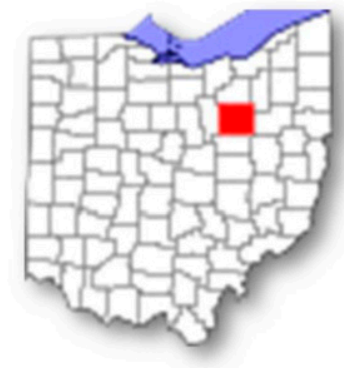

A

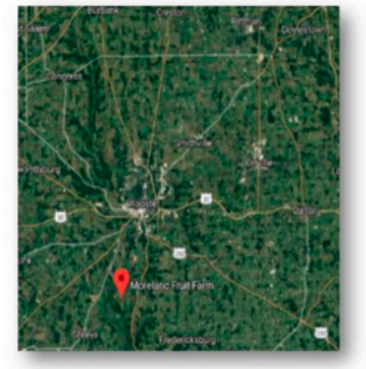

B

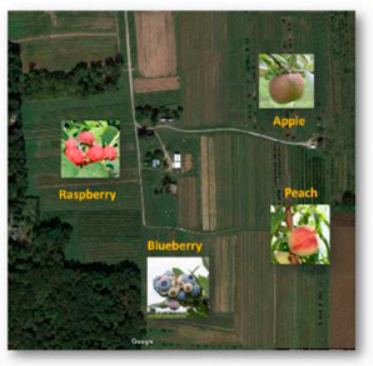

$\mathrm{C}$
Fig. 1. Location of the Moreland Fruit Farm experimental site in Wayne County, OH: maps of Ohio (A) and Wayne County (B) and floor plan of experimental plants (C). serious disease for stone fruit such as peach under warm and humid conditions (Hartman, 2007). Peach becomes increasingly susceptible to brown rot infection as the fruit ripens. Brown rot also increases in wounded peach. Application of fungicides is the primary method for controlling this disease. Peach powdery mildew, caused by Podosphaera pannosa, is another common disease when peach is grown near apple that is susceptible to powdery mildew (Blake et al., 2016).

Mummy berry caused by the fungus Monilinia vaccinii-corymbosi is one of the most serious diseases of blueberry. When mummy berry disease is established in blueberry plants, it can completely destroy the crop (Anco and Ellis, 2011). Thus, an effective fungicide spray program is critical for control of this disease. Phomopsis, caused by the fungus $\mathrm{Pho}$ mopsis vaccinii, is the most common canker disease of blueberry (Fulcher et al., 2015). It can severely decrease yield because it kills stems and causes rotted fruit. Anthracnose, caused by the fungus Elsinoe veneta, is an extremely serious disease of black raspberry throughout the United States. This disease causes the death of canes, defoliation, and reduction of fruit size and quality (Ellis, 2016b). Spraying fungicides is required to effectively control these diseases.

The hypothesis of this research was that the use of intelligent variable-rate spray application would significantly reduce the volume of pesticide needed to control insect and disease pests under commercial fruit production conditions. The objective of this research was to evaluate effects of the intelligent variable-rate spray application on pesticide use and control of insect and disease pests in fruit plants in a commercial fruit farm and to compare with the results

Table 1. Experimental fields, test plants, and pests of study for conventional constant-rate and intelligent variable-rate spray applications.

\begin{tabular}{|c|c|c|c|c|c|}
\hline \multirow[b]{2}{*}{$\underline{\text { Plant }}$} & \multicolumn{2}{|c|}{ Conventional spray } & \multicolumn{2}{|c|}{ Intelligent spray } & \multirow[b]{2}{*}{ Pests of study } \\
\hline & Rows (no.) & Plot size $(\text { acres) })^{\mathrm{z}}$ & Rows (no.) & Plot size (acres) & \\
\hline Apple & 10 & 1.90 & 8 & 1.78 & $\begin{array}{l}\text { Codling moth, oriental fruit moth, scab, powdery } \\
\text { mildew }\end{array}$ \\
\hline Peach & 5 & 1.41 & 6 & 1.41 & Oriental fruit moth, brown rot, powdery mildew \\
\hline Blueberry & 5 & 0.72 & 6 & 0.86 & $\begin{array}{l}\text { Spotted wing drosophila, mummy berry, } \\
\text { phomopsis }\end{array}$ \\
\hline
\end{tabular}

${ }^{\mathrm{z}} 1$ acre $=0.4047$ ha 


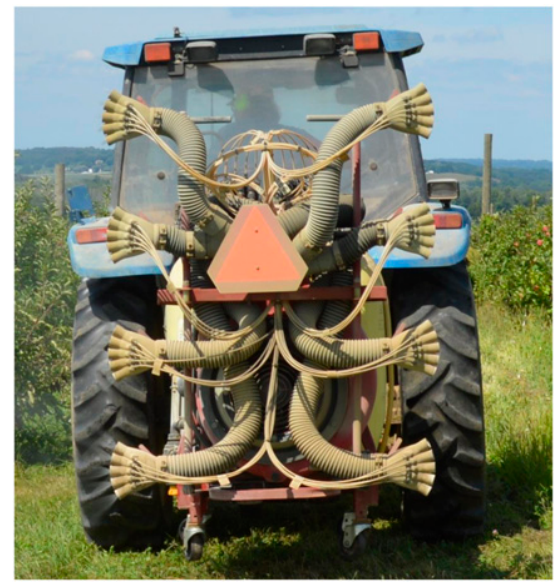

Fig. 2. Intelligent sprayer used at the Moreland Fruit Farm experimental site. It was a conventional air-assisted sprayer retrofitted with a laser-guided intelligent spray control system that included a laser scanning sensor, a speed sensor, an automatic nozzle flow rate controller, an embedded computer with algorithms, a touch screen, and variable-rate nozzles coupled with a pulse widthmodulated flow control valve on a multiport air-assisted delivery system. achieved using a constant-rate spray as the conventional standard spray practice.

\section{Materials and methods}

Fruit Farm. Field studies were conducted in a commercial fruit farm, Moreland Fruit Farm in Wayne County, $\mathrm{OH}$ [lat. $40.711711^{\circ} \mathrm{N}$, long. $81.969128^{\circ} \mathrm{W}$ (Fig. 1)], in 2017 and 2018 . There were a variety of field-grown tree fruit and small fruit in the farm, which is a typical fruit farm in the midwestern United States. Apple, peach, blueberry, and black raspberry were selected as test crops because they represented the common tree fruit and small fruit in the region. The experimental fields are shown in Fig. 1C. Experiment plots and test plants are described in Table 1 .

The field plot for each particular fruit was divided into two about equal sections: one section for intelligent spray and another section for conventional spray. For the experiments with apple, there were eight rows selected in the intelligent spray section and 10 rows in the conventional spray section

Table 2. Pesticide spray application schedules on apple, peach, blueberry, and black raspberry and accumulated degree-days (ADD) [base $\left.50^{\circ} \mathrm{F}\left(10.0^{\circ} \mathrm{C}\right)\right]$ in 2017.

\begin{tabular}{|c|c|c|c|c|c|}
\hline Date & Apple & Peach & Blueberry & Black raspberry & $\mathrm{ADD}$ \\
\hline 2 Apr. & $\mathrm{x}$ & $\mathrm{x}$ & & & 140 \\
\hline 10 Apr. & & $\mathrm{x}$ & $\mathrm{x}$ & $\mathrm{x}$ & 189 \\
\hline 12 Apr. & $\mathrm{x}$ & & & & 202 \\
\hline 18 Apr. & $\mathrm{x}$ & $\mathrm{x}$ & & & 263 \\
\hline 24 Apr. & $\mathrm{x}$ & $\mathrm{x}$ & & & 320 \\
\hline 30 Apr. & $\mathrm{x}$ & & & & 387 \\
\hline 3 May & & $\mathrm{x}$ & & & 406 \\
\hline 8 May & $\mathrm{x}$ & & & & 413 \\
\hline 22 May & $\mathrm{x}$ & $\mathrm{x}$ & & $\mathrm{x}$ & 581 \\
\hline 27 May & & & $\mathrm{x}$ & & 642 \\
\hline 5 June & $\mathrm{x}$ & $\mathrm{x}$ & $\mathrm{x}$ & $\mathrm{x}$ & 785 \\
\hline 9 June & & & $\mathrm{x}$ & $\mathrm{x}$ & 820 \\
\hline 16 June & $\mathrm{x}$ & & & & 998 \\
\hline 17 June & & & $\mathrm{x}$ & & 1024 \\
\hline 27 June & $\mathrm{x}$ & $\mathrm{x}$ & & & 1204 \\
\hline I July & & & $\mathrm{x}$ & $\mathrm{x}$ & 1284 \\
\hline 7 July & $\mathrm{x}$ & & & & 1415 \\
\hline 8 July & & $\mathrm{x}$ & $\mathrm{x}$ & $\mathrm{x}$ & 1434 \\
\hline 15 July & & & $\mathrm{x}$ & $\mathrm{x}$ & 1591 \\
\hline 17 July & $\mathrm{x}$ & & & & 1635 \\
\hline 22 July & & & $\mathrm{x}$ & & 1770 \\
\hline 25 July & $\mathrm{x}$ & & & & 1831 \\
\hline 29 July & & & $\mathrm{x}$ & & 1911 \\
\hline 5 Aug. & & & $\mathrm{x}$ & & 2048 \\
\hline 7 Aug. & $\mathrm{x}$ & & & & 2080 \\
\hline 29 Aug. & $\mathrm{x}$ & & & & 2486 \\
\hline
\end{tabular}

for tests. Spacing between every two rows was $14 \mathrm{ft}$, and tree height was 5 to $8 \mathrm{ft}$. There were various cultivars of apple in the field, and they were supported by trellis before this study. Codling moth mating disruption dispensers (isomate-CM FLEX; Pacific Biocontrol Corp., Vancouver, WA) were placed in the trees at a rate of 300 dispensers per acre in early April.

For experiments with peach, there were six rows selected in the intelligent spray section and five rows in the conventional spray section. Spacing between two rows was $22 \mathrm{ft}$, and tree height was 8 to $11 \mathrm{ft}$. The peach trees were trimmed by opencenter pruning in early spring. Oriental fruit moth mating disruption dispensers (isomate-M ROSSO, $\mathrm{Pa}$ cific Biocontrol Corp.) were placed in the trees at a rate of 150 dispensers per acre in early April.

Blueberry plots were selected with six rows for intelligent spray and five rows for conventional spray. Plant height of blueberry was 3 to 6 $\mathrm{ft}$, and spacing between every two rows was $16 \mathrm{ft}$. Black raspberry plots were selected with eight rows for intelligent spray and seven rows for conventional spray. Plant height of black raspberry was 3 to $5 \mathrm{ft}$, and spacing between two rows was $14 \mathrm{ft}$.

INTELLIGENT SPRAYER FOR TESTS. The intelligent variable-rate sprayer used for this study is shown in Fig. 2. It was a conventional air-assisted sprayer retrofitted with a laser-guided intelligent spray control system that included a laser scanning sensor, a speed sensor, an automatic nozzle flow rate controller, an embedded computer with programs, a touch screen, and 40 variable-rate nozzles on a multiport air-assisted delivery system (Shen et al., 2017). The same sprayer also had a manual control mode that discharged spray solutions at constant rates, which was used as a conventional standard sprayer for comparison tests. Each variable-rate nozzle consisted of a modified spray nozzle tip (XR8004; Spraying Systems, Wheaton, IL) coupled with a pulse width modulated flow control valve operated at the initial pressure of 35 psi.

During intelligent spray applications, the laser sensor on the sprayer scanned trees instantaneously at a rate of 43,200 points per second, and the computer program used the scanned information 
to calculate sectional tree canopy foliage volume and then converted the foliage volume to spray liquid volume for each corresponding nozzle. Immediately after the conversion, the nozzle flow rate controller manipulated individual nozzles to discharge variable flow rates within the range of 0 to $0.6 \mathrm{~L} \cdot \mathrm{min}^{-1}$ in real time based on the calculated liquid volume to match sectional canopy presence and foliage volume. Details about this intelligent sprayer design and spray output control were previously provided by Shen et al. (2017). During conventional spray applications, the intelligent variable-rate function was disabled, and all sprayer nozzles discharged at the same time at a total flow rate of $24.0 \mathrm{~L} \cdot \mathrm{min}^{-1}$.

Table 3. Pesticide spray application schedules on apple, peach, blueberry, and black raspberry and accumulated degree-days (ADD) [base $\left.50{ }^{\circ} \mathrm{F}\left(10.0^{\circ} \mathrm{C}\right)\right]$ in 2018.

\begin{tabular}{|c|c|c|c|c|c|}
\hline Date & Apple & Peach & Blueberry & Black raspberry & $\mathrm{ADD}$ \\
\hline 27 Feb. & & $\mathrm{x}$ & & & 47 \\
\hline 10 Apr. & & & $\mathrm{x}$ & $\mathrm{x}$ & 61 \\
\hline 11 Apr. & $\mathrm{x}$ & & & & 63 \\
\hline 18 Apr. & $\mathrm{x}$ & & & & 110 \\
\hline 20 Apr. & & $\mathrm{x}$ & & & 110 \\
\hline 27 Apr. & $\mathrm{x}$ & $\mathrm{x}$ & & & 139 \\
\hline 28 Apr. & & $\mathrm{x}$ & & & 139 \\
\hline 5 May & $\mathrm{x}$ & $\mathrm{x}$ & & & 227 \\
\hline 12 May & $\mathrm{x}$ & & & & 313 \\
\hline 20 May & $\mathrm{x}$ & & & & 442 \\
\hline 21 May & & & $\mathrm{x}$ & & 457 \\
\hline 28 May & $\mathrm{x}$ & $\mathrm{x}$ & & & 599 \\
\hline 29 May & & & & $\mathrm{x}$ & 627 \\
\hline 10 June & $\mathrm{x}$ & & & & 846 \\
\hline 14 June & & $\mathrm{x}$ & & & 918 \\
\hline 15 June & & & $\mathrm{x}$ & & 937 \\
\hline 23 June & $\mathrm{x}$ & $\mathrm{x}$ & $\mathrm{x}$ & $\mathrm{x}$ & 1122 \\
\hline 30 June & & & & $\mathrm{x}$ & 1280 \\
\hline 4 July & & $\mathrm{x}$ & & & 1398 \\
\hline 7 July & & & $\mathrm{x}$ & & 1463 \\
\hline 9 July & $\mathrm{x}$ & & & & 1508 \\
\hline 14 July & & $\mathrm{x}$ & $\mathrm{x}$ & & 1625 \\
\hline 26 July & $\mathrm{x}$ & & & & 1895 \\
\hline 27 July & & & $\mathrm{x}$ & & 1914 \\
\hline 28 July & & $\mathrm{x}$ & & & 1932 \\
\hline 10 Aug. & $\mathrm{x}$ & & & & 2237 \\
\hline 24 Aug. & $\mathrm{x}$ & & & & 2523 \\
\hline 11 Sept. & $\mathrm{x}$ & & & & 2938 \\
\hline
\end{tabular}

The sprayer sprayed both sides of each row at a travel speed of $\mathbf{3 . 5}$ mph for both intelligent and conventional applications. Pesticide application schedules in 2017 and 2018 were obtained from the Network for Environment and Weather Applications (Cornell University, 2019) and the Midwest Fruit Pest Management Guide (Beckerman, 2018); these are listed in Tables 2 and 3, respectively. Air temperature and precipitation during the two growing seasons are shown in Table 4.

Spray coverage on apple trees was determined with $2 \times 3$-inch water-sensitive papers (Syngenta Crop Protection, Basel, Switzerland) as described by Zhu et al. (2017). Six apple trees in each treatment section were randomly chosen for the test, and five water-sensitive papers were placed in each tree at five locations in the top, middle, bottom, and each side of the canopy. The frontal side of the water-sensitive papers faced the spray nozzles. The spray coverage on each water-sensitive paper was analyzed with a computer imaging system DepositScan as described by Zhu et al. (2011c), and the percentage of the total area of the water-sensitive paper covered by spray deposits was calculated. The DepositScan software was downloaded from the website of U.S. Department of Agriculture (2017), which was free for the public.

Assessments OF INSECTS AND DISEASES. Insect pest populations and disease severity were assessed at 1 - to 3-week intervals (Table 1 ). Populations of codling moth and oriental fruit moth in apple, oriental fruit moth in peach, and spotted wing

Table 4. Air temperature and precipitation at the experiment site during the two growing seasons of 2017 and 2018.

\begin{tabular}{llcccc}
\hline Yr & Month & Avg air temp $\left({ }^{\circ} \mathbf{F}\right)^{\mathbf{z}}$ & Maximum air temp $\left({ }^{\circ} \mathbf{F}\right)$ & Minimum air temp $\left({ }^{\circ} \mathbf{F}\right)$ & Total precipitation $(\text { inches })^{\mathbf{z}}$ \\
\hline 2017 & April & 56.1 & 82.2 & 30.0 & 3.28 \\
& May & 59.0 & 85.0 & 32.7 & 6.04 \\
& June & 68.7 & 88.4 & 48.0 & 4.92 \\
& July & 71.8 & 89.2 & 55.3 & 5.76 \\
& August & 67.9 & 87.1 & 43.3 & 0.95 \\
& September & 63.8 & 91.1 & 40.0 & 3.79 \\
& October & 55.7 & 80.5 & 29.5 & 3.52 \\
2018 & April & 44.2 & 79.5 & 23.0 & 6.18 \\
& May & 66.6 & 89.3 & 42.7 & 5.35 \\
& June & 69.5 & 91.0 & 45.0 & 6.25 \\
& July & 72.6 & 91.2 & 52.4 & 3.14 \\
August & 72.6 & 88.6 & 53.2 & 4.23 \\
September & 67.9 & 91.7 & 48.3 & 6.19 \\
October & 52.7 & 84.6 & 27.4 & 3.76 \\
\hline
\end{tabular}

${ }^{\mathrm{z}}\left({ }^{\circ} \mathrm{F}-32\right) \div 1.8={ }^{\circ} \mathrm{C}, \mathrm{l}$ inch $=2.54 \mathrm{~cm}$. 
drosophila in blueberry were monitored by codling moth trap (Delta Pherocon VI with CM-DA COMBO lure; Trécé, Adair, OK), oriental fruit moth trap (Wing-style Pherocon OFM Trap with OFM lure, Trécé), and spotted wing drosophila trap (Pherocon SWD Trap with broad spectrum lure, Trécé), respectively. Traps with three replications were placed inside the canopies of each crop in the middle row of each treatment section with spacing $100 \mathrm{ft}$ in blueberry and $150 \mathrm{ft}$ in apple and peach fields. Codling moth, oriental fruit moth, and spotted wing drosophila were counted every 1 to 3 weeks, and trap liners and lures were replaced by new ones every 4 weeks.

To assess the severity of brown rot in peach, three locations were randomly selected, and 100 fruit in each spot were examined. To assess the severity of scab and powdery mildew in apple, powdery mildew in peach, phomopsis and mummy berry in blueberry, and anthracnose in black raspberry, 20 plants were randomly selected from each test section, and the proportion of infected trees or bushes was observed and recorded on a basis of $0 \%$ (symptomless), $10 \%$ ( $10 \%$ of the plant had symptoms), and $100 \%$ (dead plant). The formula for calculating the area under the disease progress curve (AUDPC) was

$$
A_{K}=\sum_{i=1}^{N_{i}-1} \frac{\left(y_{i}+y_{i+1}\right)}{2}\left(t_{i+1}-t_{i}\right),
$$

where $t$ is the order of disease severity observation, $y_{i}$ is the disease level at $t=$ $i, y_{0}$ is the initial infection or the disease level at $t=0$ (i.e., the first disease severity observation), $A_{k}$ is the total accumulated disease level for AUDPC until $t=t_{k}$ (Madden et al., 2007).

Statistical analysis. The results were compared by paired $t$ test for different spray applications as independent variables using spreadsheet software (Excel 2016; Microsoft Corp., Redmond, WA). Comparisons between the conventional and intelligent spray applications included spray effects on the number of insect pests of codling moth, oriental fruit moth, and spotted wing drosophila per trap at an individual date; severity of diseases during a growing season; pesticide usage per year; and spray coverage. When the analysis generated a significant $F$ value $(P \leq$ 0.05 ) for treatments, different letters A and B were marked after the means. Significant differences in AUDPC were determined by analysis of variance.

\section{Results and discussion}

Apple. During the two growing seasons, codling moth pheromone traps placed in the canopies of apple trees were used to monitor the population of codling moths and evaluate

Table 5. Average numbers of codling moths and oriental fruit moths collected in traps in conventional constant-rate and intelligent variable-rate spray apple plots in 2017 . There was no statistical significance $(P \geq 0.05)$ by paired $t$ test between intelligent and conventional treatments on the same date for the same pest.

\begin{tabular}{|c|c|c|c|c|c|}
\hline \multicolumn{3}{|c|}{ Codling moths (no.) } & \multicolumn{3}{|c|}{ Oriental fruit moths (no.) } \\
\hline Date & Conventional spray & Intelligent spray & Date & Conventional spray & Intelligent spray \\
\hline 26 Apr. & 0 & 0 & 3 Apr. & 0 & 0 \\
\hline 10 May & 0 & 0 & 17 Apr. & 0 & 0 \\
\hline 15 May & 4 & 0 & 21 Apr. & 0 & 0 \\
\hline 25 May & 31 & 40 & 26 Apr. & 3 & 31 \\
\hline 21 June & 5 & 17 & 15 May & 0 & 0 \\
\hline 11 July & 5 & 3 & 25 May & 3 & 4 \\
\hline 21 July & 22 & 15 & 1 June & 1 & 1 \\
\hline 28 July & 1 & 6 & 12 June & 4 & 0 \\
\hline 7 Aug. & 23 & 15 & 21 June & 0 & 0 \\
\hline
\end{tabular}

Table 6. Effects of conventional constant-rate and intelligent variable-rate spray applications on the average numbers of codling moths in each trap in apple and oriental fruit moths in peach in 2018 . There was no statistical significance $(P \geq 0.05)$ by paired $t$ test between intelligent and conventional treatments on the same date for the same pest.

\begin{tabular}{|c|c|c|c|c|c|}
\hline \multicolumn{3}{|c|}{ Codling moths in apple (no.) } & \multicolumn{3}{|c|}{ Oriental fruit moths in peach (no.) } \\
\hline$\underline{\text { Date }}$ & Conventional spray & Intelligent spray & Date & Conventional spray & Intelligent spray \\
\hline 18 May & 0 & 0 & & & \\
\hline 6 June & 20.5 & 24.5 & & & \\
\hline 14 June & 16.0 & 9.0 & & & \\
\hline 29 June & 1.5 & 2.5 & 29 June & 0 & 0 \\
\hline 13 July & 0.5 & 1.5 & 13 July & 0 & 0 \\
\hline 6 Aug. & 1.0 & 2.5 & 6 Aug. & 0 & 0 \\
\hline
\end{tabular}



apple orchard. During the 2017 growing season, oriental fruit moth traps were also placed in the canopies of apple trees to monitor the population of oriental fruit moths and evaluate oriental fruit moth control programs in the same apple orchard. The number of codling moths and oriental fruit moths in the pheromone traps are listed in Tables 5 and 6 , respectively. The analyses failed to detect any significant difference $(P \geq$ $0.05)$ in the number of codling moth and oriental fruit moth between conventional and intelligent spray applications. This indicates that intelligent spray achieved equivalent control of codling moths and oriental fruit moths compared with conventional spray.

In 2017, apple scab and powdery mildew were monitored, and neither of these diseases was found on the leaves or fruit during the growing season. Severity of apple scab and powdery mildew in apple trees in 2018 was determined every week. No apple scab or powdery mildew appeared in conventional- or intelligent-sprayed trees. Of note, there was an apple plot in an area close to that of other experiments that were being conducted. This plot was not sprayed, as recommended by the Midwest Fruit Pest Management Guide (Beckerman, 2018), and apple scab occurred in almost all fruit. These results indicated that both intelligent and conventional spray applications codling moth control programs in the

(Tables 2 and 3 ) were equally effective for controlling apple diseases.

Peach. In 2017, no oriental fruit moths were found in traps in the peach trees treated with either conventional or intelligent spray applications. Numbers of trapped oriental fruit moth for peach in 2018 are shown in Table 6 , and no oriental fruit moths were caught during the growing season. This could be because oriental fruit moth mating disruption dispensers were used in the peach trees and insecticides were applied according to the recommendations of the Midwest Fruit Pest Management Guide (Beckerman, 2018), and no or few oriental fruit moths appeared in the field.

In 2017, neither brown rot nor powdery mildew in peach trees was found during the growing season. In 2018, severity of brown rot and powdery mildew in peach trees was determined every week. Neither brown rot nor powdery mildew appeared in conventional and intelligent spray plots. The farm owner reported that brown rot was a traditional disease that occurred severely in peach trees of the experiment site, and fruit would be damaged without pesticide applications. Thus, both intelligent and conventional spray applications effectively controlled insects and diseases in peach trees.

Blueberry. In 2017, spotted wing drosophila traps were placed during the late growing season. The

Table 7. Spotted wing drosophila in traps in conventional constant-rate and intelligent variable-rate spray blueberry plots in 2017 . There was no statistical significance $(P \geq 0.05)$ by paired $t$ test between intelligent and conventional treatments on the same date.

\begin{tabular}{lcc}
\hline & \multicolumn{2}{c}{ Spotted wing drosophila (no.) } \\
\cline { 2 - 3 } Date & Conventional spray & Intelligent spray \\
\hline 28 July & 60 & 18 \\
7 Aug. & 42 & 44 \\
14 Aug. & 29 & 37 \\
\hline
\end{tabular}

number of spotted wing drosophila in traps is shown in Table 7 . The analyses failed to detect any significant difference $(P \geq 0.05)$ in the number of spotted wing drosophila between conventional and intelligent spray applications during the three measurement dates. In 2018, spotted wing drosophila was not observed. Thus, spraying insecticides with either intelligent or conventional treatment controlled spotted wing drosophila infestation.

In 2017, neither mummy berry nor phomopsis was found during the growing season in both the conventional- and intelligent-sprayed blueberry fields. Severity of phomopsis and mummy berry in blueberry plants in 2018 is shown in Table 8 . There were no significant differences $(P \geq$ $0.05)$ in severity of phomopsis and mummy berry diseases in blueberry for intelligent spray application compared with conventional spray. The intelligent spray system was equally effective for control of insect and disease pests in blueberries compared with the conventional constant-rate spray.

BLACK RASPBERry. In 2017, no anthracnose infection occurred in the black raspberry plants for both the conventional and intelligent spray applications during the growing season. Severity of anthracnose in black raspberry in 2018 is shown in Table 9. Anthracnose occurred in June and increased from June to July and $\mathrm{Au}^{-}$ gust. Compared with the conventional spray application, anthracnose in black raspberry was reduced by $33 \%$ to $50 \%$ with the intelligent spray application.

Pesticide use. Pesticide use for conventional and intelligent spray applications in each crop are shown in Table 10. The conventional spray application rates were $81.6,54.2$, 49.3 , and $80.2 \mathrm{gal} / \mathrm{acre}$ on average for 2 years in apple, peach, blueberry, and black raspberry, respectively,

Table 8. Severity of phomopsis and mummy berry on blueberry plants in conventional (Con) constant-rate and intelligent (Int) variable-rate spray treatments in 2018. There was no statistical significance $(P \geq 0.05)$ by paired $t$ test between intelligent and conventional treatments on the same date for the same pest.

\begin{tabular}{|c|c|c|c|c|c|c|c|c|c|c|}
\hline \multirow[b]{2}{*}{ Spray type } & \multicolumn{5}{|c|}{ Phomopsis } & \multicolumn{5}{|c|}{ Mummy berry } \\
\hline & 29 June & 13 July & 6 Aug. & Avg & $\mathrm{AUDPC}^{\mathrm{z}}$ & 29 June & 13 July & 6 Aug. & Avg & AUDPC \\
\hline & & -----_\% & & --.-- & & & $--\%$ & & -.- & \\
\hline Int & 0 & 0 & 0 & 0 & $0 \mathrm{~b}$ & 0 & 0 & 0 & 0 & 0 \\
\hline
\end{tabular}

${ }^{\mathrm{z}}$ Area under the disease progress curve, based on the mean disease severity ratings made during period of 6 weeks.

${ }^{y}$ Different letters after means are significantly different $(P \leq 0.05)$. 
Table 9. Anthracnose severity on black raspberry plants in conventional constant-rate and intelligent variable-rate spray treatments in 2018 .

\begin{tabular}{|c|c|c|c|c|c|}
\hline \multirow[b]{2}{*}{ Spray type } & \multicolumn{5}{|c|}{ Anthracnose } \\
\hline & 29 June & 13 July & 6 Aug. & Avg & AUDPC $^{z}$ \\
\hline Conventional & 20 & 30 & 30 & $267 \mathrm{a}^{\mathrm{y}}$ & $1068.3 \mathrm{a}$ \\
\hline Intelligent & 10 & 20 & 20 & $16.7 \mathrm{~b}$ & $670.0 \mathrm{~b}$ \\
\hline
\end{tabular}

${ }^{\mathrm{z}}$ Area under the disease progress curve, based on the mean disease severity ratings made during period of 6 weeks.

${ }^{y}$ Different letters after means are significantly different $(P \leq 0.05)$ by paired $t$ test.

Table 10. Effects of conventional (Con) constant-rate and intelligent (Int) variable-rate spray applications on pesticide use in different plants in 2017 and 2018.

\begin{tabular}{|c|c|c|c|c|c|c|c|c|}
\hline \multirow[b]{2}{*}{ Application parameter } & \multicolumn{2}{|c|}{ Apple } & \multicolumn{2}{|c|}{ Peach } & \multicolumn{2}{|c|}{ Blueberry } & \multicolumn{2}{|c|}{ Black raspberry } \\
\hline & Con & Int & Con & Int & Con & Int & Con & Int \\
\hline \multicolumn{9}{|l|}{2017} \\
\hline Avg use (gal) & 153 & 49.9 & 49.9 & 38.0 & 30.1 & 20.1 & 110 & 53.1 \\
\hline Area (acres) & 1.90 & 1.78 & 1.41 & 1.41 & 0.72 & 0.86 & 1.41 & 1.33 \\
\hline Avg vol (gal/acre) & $80.5 \mathrm{a}^{\mathrm{y}}$ & $28.0 \mathrm{~b}$ & $35.4 \mathrm{a}$ & $27.0 \mathrm{~b}$ & $41.8 \mathrm{a}$ & $23.4 \mathrm{~b}$ & $78.0 \mathrm{a}$ & $39.9 \mathrm{~b}$ \\
\hline Total use (gal) & 2202 & 974 & 1131 & 743 & 287 & 170 & 462 & 190 \\
\hline Avg use (gal) & 157 & 70.0 & 103 & 67.9 & 40.9 & 24.0 & 116 & 48.1 \\
\hline Area (acres) & 1.90 & 1.78 & 1.41 & 1.41 & 0.72 & 0.86 & 1.41 & 1.33 \\
\hline Avg vol (gal/acre) & 82.6 a & $39.3 \mathrm{~b}$ & $73.0 \mathrm{a}$ & $48.2 \mathrm{~b}$ & $56.8 \mathrm{a}$ & $27.9 \mathrm{~b}$ & $82.3 \mathrm{a}$ & $36.2 \mathrm{~b}$ \\
\hline Reduction (\%) & & 52.4 & & 34.0 & & 50.9 & & 56.0 \\
\hline
\end{tabular}

${ }^{\mathrm{z}} 1 \mathrm{gal}=3.7854 \mathrm{~L}, \mathrm{l}$ acre $=0.4047 \mathrm{ha}, \mathrm{l}$ gal $/$ acre $=9.3540 \mathrm{~L} \cdot \mathrm{ha}^{-1}$.

${ }^{\mathrm{y}}$ Different letters after means in the same year and same crop are significantly different at the $P \leq 0.05$ level by paired $t$ test.

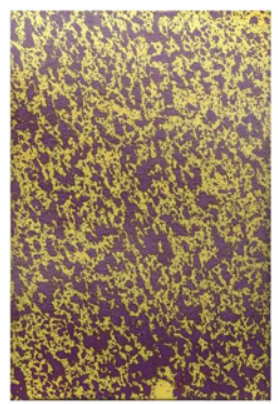

A

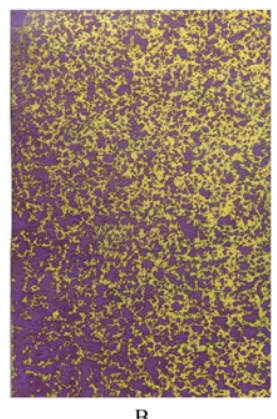

B
Fig. 3. Spray deposits (blue spots) discharged from conventional spray (A) and intelligent spray (B) applications on water-sensitive papers placed in apple trees.

while the intelligent spray application rates were $33.7,37.6,25.7$, and $38.1 \mathrm{gal} /$ acre in the corresponding plants. Thus, the intelligent spray application reduced pesticide use by $58.7 \%$ in apple, $30.6 \%$ in peach, $47.9 \%$ in blueberry, and $52.5 \%$ in black raspberry on average for 2 years compared with conventional spray. Spray deposits (Fig. 3) for conventional and intelligent spray applications in apple were $53.7 \%$ and $64.0 \%$ covering on water sensitive papers, respectively. There was no statistical difference $(P \geq 0.05)$ in spray coverage between conventional and intelligent spray applications.

Intelligent spray application reduced the pesticide used in apple, blueberry, and black raspberry by approximately half, which was comparable to the spray reductions in the experiments by Chen et al. (2013a) in apple, and another experiment in london planetree (Platanus $\times$ acerifolia) in a commercial nursery (Chen et al., 2019). Intelligent spray application reduced pesticide use by $30.6 \%$ on average for the two growing seasons in peach. In another experiment, the intelligent spray system reduced pesticide use by $32.6 \%$ in birch (Betula sp.) trees with large canopies and narrow spacing (Chen et al., 2019). The peach trees in the current research were larger than the apples, averaging $10 \mathrm{ft}$ in height in Aug. 2018, and had large canopies that overlapped, leaving no empty space between plants within the row. Thus, intelligent spray application tended to reduce pesticide use more in smaller trees than in larger and denser trees.

Furthermore, there was no statistical difference in spray coverage between conventional and intelligent spray applications in apple, whereas the intelligent spray significantly reduced pesticide use to a similar degree as a previous study in multiple-row nursery trees (Zhu et al., 2017). This suggests that intelligent spray application reduced the amount of offtarget drift of pesticides reaching the ground and air, thereby reducing adverse impact to the environment (Chen et al., 2013b). Therefore, compared with the conventional constant-rate application, the intelligent variable-rate spray application reduced pesticide use significantly while maintaining equivalent spray deposition quality on plant canopy and comparable or even better control of pest insects and diseases. The lower total water volume used by the intelligent sprayer might have also led to better levels of disease control than conventional sprayer because of less leaf wetness.

\section{Conclusions}

Compared with the conventional constant-rate sprayer, the intelligent variable-rate sprayer used $30.6 \%$ to $58.7 \%$ less pesticides in four fruit crops and was of greater benefit to plants with 
small canopies and with relatively wide spacing between plants. This research also demonstrated that treatments with the intelligent spray application were equally or more effective than conventional sprays for control of insect and disease pests in fruit plants. Thus, in this study, the intelligent spray system, along with the mating disruption of insects, provided a highly efficient and environmentally friendly pesticide spray technology for the fruit industry to reduce costs by reducing pesticide use. Comparison of pesticide application alone to control insect pests with untethered pest pressure is yet to be demonstrated. It should be noted that the product of this new spray technology was released into the market for growers to retrofit on their existing sprayers to achieve intelligent variablerate functions (Smart Guided Systems, Indianapolis, IN).

\section{Literature cited}

Amarasekare, K.G. and P.W. Shearer. 2017. Stability of Cacopsylla pyricola (Hemiptera: Psyllidae) populations in pacific northwest pear orchards managed with long-term mating disruption for Cydia pomonella (Lepidoptera: Tortricidae). Insects 8:105.

Anco, D.J. and M.A. Ellis. 2011. Mummy berry of blueberry. 9 May 2019. <https:// ohioline.osu.edu/factsheet/plpathfru-46>.

Beckerman, J. 2018. Midwest fruit pest management guide 2019-2020. 21 Dec. 2018. <https://ag.purdue.edu/hla/ hort/documents/id-465.pdf>.

Blake, J., N. Doubrava, R.W. Miller, Jr., G. Schnabel, and J. Williamson. 2016. Peach diseases. 9 May 2019. <https:// hgic.clemson.edu/factsheet/peachdiseases>.

Brunner, J.F. 1993. Codling moth. Orchard pest management online. 6 May 2019. <http://treefruit.wsu.edu/cropprotection/opm/codling-moth>.

Brunner, J.F. and R.E. Rice. 1993. Oriental fruit moth. Orchard pest management online. 6 May 2019. <http://treefruit.wsu. edu/crop-protection/opm/oriental-fruitmoth>.

Chen, L., M. Wallhead, H. Zhu, and A. Fulcher. 2019. Control of insects and diseases with intelligent variable-rate sprayers in ornamental nurseries. J. Environ. Hort. 37:90-100.

Chen, Y., H. Zhu, and H.E. Ozkan. 2012. Development of a variable rate sprayer with laser scanning sensor to synchronize spray outputs to tree structures. Trans. Amer. Soc. Agr. Biol. Eng. 55:773-781.

Chen, Y., H.E. Ozkan, H. Zhu, R.C. Derksen, and C.R. Krause. 2013a. Spray deposition inside tree canopies from a newly developed variable rate air-assisted sprayer. Trans. Amer. Soc. Agr. Biol. Eng. 56:1263-1272.

Chen, Y., H. Zhu, H.E. Ozkan, R.C. Derksen, and C.R. Krause. 2013b. Spray drift and off-target loss reductions with a precision air-assisted sprayer. Trans. Amer. Soc. Agr. Biol. Eng. 56:1273-1281.

Cornell University. 2019. Network for environment and weather applications. 3 Dec. 2019. <http://newa.cornell.edu/ index.php? page $=$ apple-insects $>$.

Ellis, M.A. 2008. Scab of apple. 9 May 2019. <https://ohioline.osu.edu/ factsheet/plpath-fru-23>.

Ellis, M.A. 2016a. Apple powdery mildew. 9 May 2019. <https://ohioline.osu. edu/factsheet/plpath-fru-2l $>$.

Ellis, M.A. 2016b. Anthracnose of raspberry and blackberry. 9 May 2019. <https:// ohioline.osu.edu/factsheet/plpath-fru-27>.

Fulcher, A., N.W. Gauthier, W.E. Klingeman, F. Hale, and S.A. White. 2015. Blueberry culture and pest, disease, and abiotic disorder management during nursery production in the southeastern U.S.: A review. J. Environ. Hort. 33:33-47.

Hartman, J.R. 2007. Peach fruit diseases. 9 May 2019. <https://plantpathology. ca.uky.edu/files/ppfs-fr-t-09_0.pdf>.

Haye, T., P. Girod, A.G.S. Cuthbertson, X.G. Wang, K.M. Daane, K.A. Hoelmer, C. Baroffio, J.P. Zhang, and N. Desneux. 2016. Current SWD IPM tactics and their practical implementation in fruit crops across different regions around the world. J. Pest Sci. 89:643-651.

Madden, L.V., G. Hughes, and F. van den Bosch. 2007. The study of plant disease epidemics. Amer. Phytopathol. Soc., St. Paul, MN.

Mazzi, D., E. Bravin, M. Meraner, R. Finger, and S. Kuske. 2017. Economic impact of the introduction and establish- ment of Drosophila suzukii on sweet cherry production in Switzerland. Insects 8:18, doi: 10.3390/insects8010018.

Shen, Y., H. Zhu, H. Liu, Y. Chen, and E. Ozkan. 2017. Development of a laserguided embedded-computer-controlled air-assisted precision sprayer. Trans. Amer. Soc. Agr. Biol. Eng. 60:1827-1838.

Stover, E., J. Salvatore, and F. Wirth. 2003. Pesticide spray reduction from using a sensor actuated spray system in Indian River grapefruit. HortTechnology 13:178-181.

UMass Extension. 2018. Integrated pest management program. 3 Dec. 2019. $<$ https://ag.umass.edu/integrated-pestmanagement/ipm-guidelines/apple>.

U.S. Department of Agriculture. 2017. DepositScan. 4 Dec. 2019. <http://ars.usda. gov/mwa/wooster/atru/depositscan>.

Zhu, H., H. Liu, Y. Shen, H. Liu, and R.H. Zondag. 2017. Spray deposition inside multiple-row nursery trees with a laser-guided sprayer. J. Environ. Hort. 35:13-23.

Zhu, H., J. Atland, R.C. Derksen, and C.R. Krause. 201la. Optimal spray application rates for ornamental nursery liner production. HortTechnology 21:367-375.

Zhu, H., M. Salyani, and R.D. Fox. 2011 c. A portable scanning system for evaluation of spray deposit distribution. Comput. Electron. Agr. 76:38-43.

Zhu, H., R.C. Derksen, H. Guler, C.R. Krause, and H.E. Ozkan. 2006a. Foliar deposition and off-target loss with different spray techniques in nursery applications. Trans. Amer. Soc. Agr. Biol. Eng. 49:325-334.

Zhu, H., R.D. Brazee, R.C. Derksen, R.D. Fox, C.R. Krause, H.E. Ozkan, and K. Losely. 2006b. A specially designed airassisted sprayer to improve spray penetration and air jet velocity distribution inside dense nursery crops. Trans. Amer. Soc. Agr. Biol. Eng. 49:1285-1294.

Zhu, H., R.H. Zondag, C.R. Krause, J. Merrick, and J. Daley. 2011b. Reduced use of pesticides for effective controls of arthropod pests and plant diseases. J. Environ. Hort. 29:143-151.

Zhu, H., R.H. Zondag, R.C. Derksen, M. Reding, and C.R. Krause. 2008. Influence of spray volume on spray deposition and coverage within nursery trees. J. Environ. Hort. 26:51-57. 